$10-2016$

\title{
Minority Protection and Democratic Consolidation: The role of European Integration in the Republic of Macedonia
}

\author{
Eltion Meka \\ University of New York Tirana
}

Follow this and additional works at: https://digitalcommons.usf.edu/gsp

\section{Recommended Citation}

Meka, Eltion (2016) "Minority Protection and Democratic Consolidation: The role of European Integration in the Republic of Macedonia," Genocide Studies and Prevention: An International Journal: Vol. 10: Iss. 2: 23-37.

DOI:

http://dx.doi.org/10.5038/1911-9933.10.2.1350

Available at: https://digitalcommons.usf.edu/gsp/vol10/iss2/5

This Articles is brought to you for free and open access by the Open Access Journals at Digital Commons @ University of South Florida. It has been accepted for inclusion in Genocide Studies and Prevention: An International Journal by an authorized editor of Digital Commons @ University of South Florida. For more information, please contact digitalcommons@usf.edu. 


\title{
Minority Protection and Democratic Consolidation: The Role of European Integration in the Republic of Macedonia
}

\author{
Eltion Meka \\ University of New York Tirana \\ Tirana, Albania
}

\begin{abstract}
The purpose of this article is to take stock of the European integration literature in reference to Eastern Europe in order to better understand how international forces affect minority rights. The article will focus on the status of the Albanian minority in the case of the Republic of Macedonia and attempt to illustrate how European integration has contributed to or hindered ethnic reconciliation between the ethnic Albanian minority and Macedonian majority through a historical-sociological analysis. Additionally, by linking the protection of minority rights to democratic consolidation, this article will show how the former is largely dependent on the latter.
\end{abstract}

Keywords: democratization, Eastern Europe, European integration, ethnic politics, ethnic reconciliation, Macedonia, minority rights

\section{Introduction}

At the time of writing, the Srebrenica Genocide of July 1995 is mourning its 20th anniversary. It has been over two decades since the beginning of the Yugoslav Wars of the 1990s, yet some of the former republics of the Yugoslav Federation are still struggling with building and maintaining modern democratic states. The Bosnian experiment has been an utter failure; Kosovo remains a contested state; while the Republic of Macedonia (henceforth Macedonia), once the frontrunner of European integration in the Western Balkans has fallen back on hard times. There are a number of peculiarities respective to each of the three aforementioned cases. However, what is common to all three has been minority rights issues and the failure to properly consolidate a modern democratic state.

The European Union (EU) has acted as a powerful stabilizing force in the region by providing a pathway to full EU membership. However, due to a combination of factors - enlargement fatigue after the 2004/07 Eastern enlargement and the recent global financial crisis - the EU's influence in the Western Balkans has deteriorated as the region's leaders have realized that another EU enlargement is not on the horizon for the near future. Coincidentally or not, at a time when the EU's normative power in the region is being questioned, a number of states have reverted back toward authoritarian tendencies, with Macedonia being a prime example of this trend. The EU therefore, seems to be repeating a mistake it made in the 1990s. As British historian Garton Ash argued in a 1998 Foreign Affairs article, after the collapse of communism, EU leaders were too preoccupied with addressing the Union's internal concerns, that they allowed Sarajevo to burn. ${ }^{1}$

The post-communist transformation of Eastern Europe and the Western Balkans in particular were unique for a number of reasons as they relate to this article. Unlike previous political transformations from the developing world, East European transformations had to initiate change from two fronts - political as well as economic. Political in the sense of regime change, and economic in the sense of developing market economics. If the dual nature of Eastern transformations did not pose difficult enough choices for political leaders, Brzezinski has argued that the collapse of communism turned Eastern Europe into a "volcano of nations". ${ }^{2}$ Offe has interpreted this to mean that in addition to the dual nature of Eastern transitions, the question of nationhood for a number of states has resulted in a "triple transition". ${ }^{3}$

The purpose of this article will therefore be to analyze the political transformation of Macedonia through a historical-sociological analysis with a particular reference to the status of the Albanian minority. Even though Macedonia hosts a number of other minorities, it is the Albanian one which has been the most difficult to accommodate, as well as the one through which ethnic politics have revolved around. As Macedonian scholar Daskalovski has argued, among all factors

\footnotetext{
${ }^{1}$ Timothy Garton Ash, “Europe's Endangered Liberal Order,” Foreign Affairs 77, (1998), 61.

${ }^{2}$ Zbigniew Brzezinski, “Post-Communist Nationalism," Foreign Affairs 68, no. 5 (1989), 1.

${ }^{3}$ Claus Offe, "Capitalism by Democratic Design? Democratic Theory Facing the Triple Transition in East Central Europe," Social Research 71, no. 3 (1991).
} 
that have influenced the political transformation of Macedonia, none has had as great an effect as the "disputing of the character of the state by Macedonian Albanians." ${ }^{\prime 4}$ This is not to neglect the status of other non-majority communities in Macedonia, whose input is also relevant for the consolidation of democracy. Rather, by focusing on the largest non-majority group, the paper will be better positioned to analyze the development of minority rights, and the impact such rights have had on the consolidation of democracy.

Macedonia was chosen as a case study because it represents a rare case through which to study the situation of minorities in the democratic transition of a post-conflict or post-genocidal society. Genocide in the context of this article is defined as a political process that seeks to violently remove minorities from a political community or society..$^{5}$ Additionally, according to Gurr, Macedonia represents a clear case of genocide prevention through the international community's action early in the conflict. ${ }^{6}$ Macedonia therefore provides an important case study for post-conflict/genocidal studies and a number of anomalies as it relates to democratic theory and minority rights. For example, Macedonia was the first Western Balkan state to sign a Stabilization and Association Agreement with the EU in 2001, which was supposed to serve as a stepping-stone for full EU membership. In 2005, Macedonia again became the first state in the region to be granted official EU candidate status, which was to signal the beginning of accession negotiations. Still, a decade later and negotiations are yet to begin. In fact, along with Turkey, which has been an official candidate since 1997, Macedonia has failed to satisfy EU demands in order to begin negotiations despite a decade of candidacy status. According to the 2014 Progress Report, which the EU produces annually to monitor a candidate's progress, "the EU accession process for the former Yugoslav Republic of Macedonia is at an impasse."7 The European integration literature has long established that the prospect for EU membership generates support for the consolidation of democracy. However, Macedonia seems to have resisted this theoretical expectation. Therefore, as defined by Eckstein, the Macedonian case will be regarded as a heuristic case study through which it would be possible to seek out potentially generalizable relations between European integration, democratic consolidation and minority rights. ${ }^{8}$

It should also be emphasized at this early point, that this article will analyze the democratization and minority rights literatures concomitantly in order to better illustrate the relationship between the two sets of literatures. It is the argument of this article that democratic consolidation and minority rights are mutually inclusive. The article therefore asks: What is the relationship between democratic consolidation and minority rights in the case of Macedonia, and what role has European integration played in this relationship? In order to address the stated question, the first part of this article will take stock of the European integration literature as it relates to democratic consolidation and minority rights.

${ }^{4}$ Zhidas Daskalovski, “Democratic Consolidation and the 'stateness' Problem: The Case of Macedonia," The Global Review of Ethnopolitics 3, no. 2 (2004), 52.

According to the 2002 Macedonian census, Macedonians consist of $64.2 \%$ of the population, Albanians $25.2 \%$, Turks $3.9 \%$, Roma $2.7 \%$, Serbs $1.8 \%$, Bosnians $0.8 \%$, and Vlachs $0.5 \%$.

${ }^{5}$ According to Shaw, "Genocide is a form of violent social conflict or war, between armed power organizations that aim to destroy civilian social groups and those groups and other actors who resist this destruction. Genocidal action is action in which armed power organizations treat civilian social groups as enemies and aim to destroy their real or putative social power, by means of killing, violence and coercion against individuals whom they regard as members of the groups." See: Martin Shaw, What is genocide?, $2^{\text {nd }}$ ed. (Cambridge: Polity Press, 2015), 193.

${ }^{6}$ Ted Robert Gurr, "Options for the prevention and mitigation of genocide: strategies and examples for policy-makers," Politorbis 47, no. 2 (2009).

Although the Macedonian case does not represent a clear post-genocidal case, Gurr has argued that Macedonia represents a rare case in which the international community acted proactively to try and prevent potential genocidal violence (Gurr, Options for the prevention and mitigation of genocide: strategies and examples for policy-makers). Furthermore, the establishment of Macedonia as a state cannot be separated from the genocidal social and political context across the Balkans region in the 1990s which-to borrow a phrase from Hinton's study of genocidal social processes - reified "manufactured identity-based differences" between people along ethnic and religious lines. See: Alexander Hinton, Why Did They Kill? Cambodia in the Shadow of Genocide (Berkeley: University of California Press, 2005), 211.

${ }^{7}$ European Commission, The former Yugoslav Republic of Macedonia Progress Report, Brussels, (October 2014$) 1$.

${ }^{8}$ Harry Eckstein, "Case Study and Theory in Political Science," in Handbook of Political Science, Vol. 3, ed. Fred I. Greenstein and Nelson W. Polsby (Reading: Addison Wesley Publishing Company, 1975), 104. 
The second part will take an empirical look at the Macedonian case in order to contrast theoretical expectations with empirical realities. The third part will engage in a discussion, while part four will conclude the article.

\section{Surveying the Literature}

This article will work under the argument that democracy promotion, as applied through the European integration process encompasses the promotion of minority rights as well. At the conceptual level this should not be a problem. One can make a very strong argument that democracy promotion by definition encompasses the equal representation of the constituent minorities of a given state. However, this fusion becomes problematic when thinking of causal mechanisms, as the promotion of democracy requires different strategies and instruments from the promotion of minority rights when thinking of causal models, such as what type of promotion works and under what conditions. Thus, we must bear in mind this analytical difficulty when attempting to fuse the two concepts together. Nonetheless, this article will attempt to bifurcate the impact of the European integration process in Macedonia into two parts - the impact on democracy and the impact on minority rights.

The theoretical argument that European integration contributes to the consolidation of democracy first emerged after the Southern Enlargement of the EU in which Greece, Portugal, and Spain acceded into the European Economic Community. Since the 1980s democracy promotion through European integration, or otherwise referred to as the international dimension of democratization, has emerged as a growing body of literature in political science and international relations. ${ }^{9}$ The relationship between international and domestic forces in the process of democratization, however, remains unclear. Despite a large body of literature showing that a relationship exists between international democracy promotion and domestic change, the causal mechanisms of this relationship remain ambiguous. For example, in a recent assessment of the impact of European integration in Eastern Europe, Vachudova argues that despite an overreaching consensus, that under certain conditions external actors are able to make a positive contribution to democratization, the type of domestic change external actors are able to bring about remains unclear. ${ }^{10}$ In an influential earlier work, Vachudova, while reaching a similar conclusion was able to show how domestic factors, such as whether the local elites represented liberal or illiberal tendencies, mitigated the impact of European integration. ${ }^{11}$

While Vachudova's findings were able to show how domestic forces mitigate international forces, another set of literature has focused on the varieties of democracy promotion. Through an analysis of 36 countries in the immediate neighborhood of the EU (Eastern Europe and the Mediterranean) Schimmelfennig and Scholtz find that the only incentive to prove effective in compelling democratic reforms has been the offer of EU membership..$^{12}$ According to the authors, the conditionality principle, which the EU applies to all recipients of its democracy aid, proved

\footnotetext{
${ }^{9}$ Peter Burnell, "Promoting Democracy," Government and Opposition 48, no. 2 (2013): 265-287; Heather Grabbe, The EU's Transformative Power: Europeanization through Conditionality in Central and Eastern Europe (New York: Palgrave Macmillan, 2006); Jon C. Pevehouse, “Democracy from the Outside-in? International Organizations and Democratization." International Organization 56, no. 3 (2002): 515-549; Paul Poast and Johannes Urpelainen, "How International Organizations Support Democratization: Preventing Authoritarian Reversals Or Promoting Consolidation?," World Politics 67, no. 1 (2015): 72-113; Geoffrey Pridham, Designing Democracy: EU Enlargement and Regime Change in Post-Communist Europe (New York : Palgrave Macmillan, 2005); Jacques Rupnik and Jan Zielonka, "Introduction: The State of Democracy 20 Years on Domestic and External Factors," East European Politics E Societies 27, no. 1 (2013): 3-25; Milada Anna Vachudova, "External Actors and Regime Change: How Post-Communism Transformed Comparative Politics," East European Politics and Societies and Cultures 29, no. 2 (2015): 519-530; Laurence Whitehead, The International Dimensions of Democratization: Europe and the Americas: Europe and the Americas (Oxford: Oxford University Press, 2001).

${ }^{10}$ Milada Anna Vachudova, "External Actors and Regime Change: How Post-Communism Transformed Comparative Politics," East European Politics and Societies and Cultures 29, no. 2 (2015), 523.

${ }^{11}$ Milada Anna Vachudova, Europe Undivided: Democracy, Leverage, and Integration After Communism (Oxford: Oxford University Press, 2005), 1-24.

${ }^{12}$ Frank Schimmelfennig and Hanno Scholtz, "EU Democracy Promotion in the European Neighbourhood Political Conditionality, Economic Development and Transnational Exchange," European Union Politics 9, no. 2 (2008).
} 
effective only when a credible membership incentive was offered. Ethier takes a broader survey of democracy promotion by comparing EU, US, and World Bank initiatives and finds that conditional approaches work better than incentivized approaches; while at the same time strengthening the role of EU enlargement in democracy promotion by showing that conditionality works only in cases in which full EU membership is offered. ${ }^{13}$ While the literature shows that EU membership contributes to democratization, it remains unclear as to what type of political systems such as, parliamentary or presidential, multiparty or two-party, are better effected by democracy promotion.

The efficacy of human rights promotion is equally unclear. According to Moravcsik, "the most important preconditions for the creation of and compliance with the sort of highly refined regime norms found in Europe are strong pre-existing norms, practices and institutions of liberal democracy, which permit causal mechanisms to operate through civil society and semiautonomous government institutions." ${ }^{14}$ The first part of Moravcsik's findings are clear-the presence of preexisting liberal norms are a precondition for the effective implementation of human rights regimes. The latter part, however, is ambiguous and it is precisely this part that human rights promoters struggle with. It is the creation of stable and effective civil society movements that poses difficulties for effective human rights protection. The highly influential edited volume of Risse, Ropp and Sikkink, The Power of Human Rights, reaches a similar conclusion: "The more open a society and culture to Western ideas and the more a country had a liberal past which included the recognition of human rights, the less likely it was that norm-violating governments would deny the validity of the international norms." ${ }^{15}$ In other words, as a number of other studies have concluded, international forces play only a secondary role as the adoption of minority protection legislation has largely been explained by domestic factors. ${ }^{16}$ Mitchell makes an eloquent argument in reference to the promotion of minority rights by stating that there is a limited extent to which we can expect international forces to change hearts and minds among groups in Eastern Europe. ${ }^{17}$

Yet, even if we were to assume that the promotion of human rights would have a universal effect across cases, there still remain a number of important questions in determining the components of the promotion strategy. As Subotić has recently argued in reference to the post-conflict transitions of Eastern Europe, transitional justice scholarship has yet to answer important questions such as: How can a transitional justice system be setup in conjunction with a political transition; are the two compatible; what is the role of sequencing; and more importantly, should transitional justice systems be setup in illiberal democracies. ${ }^{18}$ Nitzova perhaps gives the most accurate account of the difficulty in assimilating Eastern European nationalist movements into the democratization process by arguing that unlike Western European nationalist movements which followed the pattern of "state first, nation second", the reverse pattern appears to be the case in Eastern Europe. ${ }^{19}$ The difficulty of assimilating nationalist movements in Eastern Europe therefore rests at the heart of state formation which the democratization literature has labeled as an absolute necessity for democratic consolidation. As Linz and Stepan have argued, "without a state, no modern democracy

\footnotetext{
${ }^{13}$ Diane Ethier, "Is Democracy Promotion Effective? Comparing Conditionality and Incentives," Democratization 10, no. 1 (2003).

${ }^{14}$ Andrew Moravcsik, “Explaining International Human Rights Regimes: Liberal Theory and Western Europe.” European Journal of International Relations 1, no. 2 (1995), 184.

${ }^{15}$ Thomas Risse, Stephen C. Ropp, and Kathryn Sikkink, The Power of Human Rights: International Norms and Domestic Change (New York: Cambridge University Press, 1999), 272.

${ }^{16}$ James A. Mitchell, “The Assimilation of Racial Minorities into Central Eastern European Societies in the 21st Century: Central Eastern and Western Europe in Comparative Perspective," J Pol Sci Pub Aff 3, no. 1 (2015): 1-5; Melanie H. Ram, "Democratization through European Integration: The Case of Minority Rights in the Czech Republic and Romania," Studies in Comparative International Development 38, no. 2 (2003): 28-56; István Gergő Székely and István Horváth, "Diversity Recognition and Minority Representation in Central and Southeast Europe: A Comparative Analysis," Nationalities Papers 42, no. 3 (2014): 426-448.

${ }^{17}$ Mitchell, The Assimilation of Racial Minorities, 5.

${ }^{18}$ Jelena Subotić, "Out of Eastern Europe Legacies of Violence and the Challenge of Multiple Transitions." East European Politics \& Societies 29, no. 2 (2015), 410.

${ }^{19}$ Petya Nitzova, “Bulgaria: Minorities, Democratization, and National Sentiments.” Nationalities Papers 25, no. 4 (1997), 736.
} 
is possible." ${ }^{20}$ Thus, while transitioning societies are attempting on the one hand to consolidate a democratic system, on the other hand they are simultaneously struggling with the formation of a modern state.

The Macedonian transition to democracy following the Yugoslav Wars of the 1990s represents an ideal case that infused democratization and nation building. As Daskalovski has argued, the "stateness" question in the Macedonian case has perhaps been the biggest issue in preventing the consolidation of democracy. ${ }^{21}$ European integration, however, according to Subotic has not contributed to addressing the "stateness" question, as post-conflict Balkans leaders have prioritized EU accession and only superficially and reluctantly carried out political reforms. ${ }^{22}$ The effect that European integration has had on the Balkans, argues Subotic, is that it has instrumentalized transitional justice into a political tool which elites use to mobilize popular support. ${ }^{23}$ Furthermore, according to Koinova, the EU has advanced contradictory messages in Macedonia. ${ }^{24}$ On the one hand, democratization initiatives as outlined in the 1993 Copenhagen Criteria for EU membership have consisted of one component of EU promotion strategies; while on the other hand, more pertinent security concerns have consisted of the second component. Koinova goes on to argue that as a result of the EU's contradictory messages, Macedonian elites have learned to play a twolevel game: having become cognizant that security concerns matter more to the international community than democratization concerns, politicians have learned to prioritize security issues and advance nationalist goals, while only minimal advancement has taken place in the fields of human and minority rights. ${ }^{25}$ Koinova's findings therefore suggest that the impact of European integration in advancing human and minority rights has been only minimal in the case of Macedonia.

The Balkan experience with European integration is also echoed by the Slovakian experience. Through the analysis of the Slovak case, Nedelsky concludes that the combination of illiberal nationbuilding with authoritarian tendencies has a strong potential to result in an authoritarian regime. ${ }^{26}$ Macedonia in this respect seems to be following in the footsteps of Slovakia in the late 1990's, which risked EU accession as a result of the authoritarian tendencies of the Mečiar government. However, unlike the Slovakian case in which the EU applied extensive public pressure in order to secure domestic change, in the Macedonian case such pressure is absent. Thus under certain conditions, European integration can have a paradoxical effect that strengthens and exacerbates ethnic divides rather than ameliorating them.

Bieber has even gone a step further by arguing that international actors have institutionalized ethnicity by legitimizing ethnic divisions. ${ }^{27}$ Following the signing of the Ohrid Framework Agreement in August of 2001 which ended the armed conflict between ethnic Albanians and the Macedonian Government, Engstrom warned that the agreement might end up having the opposite effect to that indented by undermining state capacity and hindering ethnic reconciliation. ${ }^{28} \mathrm{~A}$ decade and a half later, Popovska and Ristoska have reached precisely that conclusion by arguing that Macedonia has not shown any signs of ethnic reconciliation..$^{29}$

\footnotetext{
${ }^{20}$ Juan Linz and Alfred Stepan, Problems of Democratic Transition and Consolidation: South America, Southern Europe, and PostCommunist Europe (Baltimore: Johns Hopkins University Press, 1996), 17.

${ }^{21}$ Daskalovski, Democratic Consolidation and the 'stateness' Problem. 52.

${ }^{22}$ Subotić, Out of Eastern Europe Legacies of Violence, 411.

${ }^{23}$ Ibid., 416.

${ }^{24}$ Maria Koinova, "Challenging Assumptions of the Enlargement Literature: The Impact of the EU on Human and Minority Rights in Macedonia," Europe-Asia Studies 63, no. 5 (2011).

${ }^{25}$ Ibid.

${ }^{26}$ Nadya Nedelsky, “Constitutional Nationalism's Implications for Minority Rights and Democratization: The Case of Slovakia," Ethnic and Racial Studies 26, no. 1 (2003), 122.

${ }^{27}$ Florian Bieber, Institutionalizing Ethnicity in the Western Balkans: Managing Change in Deeply Divided Societies (Flensburg: European Centre for Minority Issues Flensburg, 2004), 9.

${ }^{28}$ Jenny Engstrom, "Multi-Ethnicity Or Bi-Nationalism-the Framework Agreement and the Future of the Macedonian State," JEMIE 1 (2002), 3.

${ }^{29}$ Biljana Popovska and Zhanet Ristoska, "Process of Reconciliation in a Postconflict Macedonia," Academicus International Scientific Journal 11 (2015), 74.
} 
The literature on democracy and human rights promotion has shown considerable gaps, while the EU itself has officially recognized that there is no "ready-made recipe for political reform; while reforms take place differently from one country to another [emphasis added]." ${ }^{30}$ The political transformation of Macedonia has in many respects epitomized the difficulty of a multiple transition particularly at it relates to its "stateness" problem. The literature itself has also shown that, under certain conditions, European integration can have a number of unintended consequences. The following two sections will therefore look at the empirical realities of the Macedonian transformation through a historical-sociological analysis in order to better understand how democracy and human rights promotion through European integration have affected minority rights and the consolidation of democracy.

\section{A Historical-Sociological Analysis}

Despite being the frontrunner for European integration in the Western Balkans, recent political crisis in Macedonia has caused the country's integration process to reach an impasse. In February of 2015, the main opposition to the Gruevski government began leaking recordings of illegal wiretappings of some 5,000 officials, including high-level officials as well as the Prime Minister Gruevski himself. ${ }^{31}$ According to the EU's recent investigation of the wiretaps, the current government has allegedly been involved in a number of illegal activities such as "electoral fraud, corruption, abuse of power and authority, conflict of interest, blackmail, extortion (pressure on public employees to vote for a certain party with the threat to be fired), criminal damage, severe procurement procedure infringements aimed at gaining an illicit profit, nepotism and cronyism." ${ }^{32}$ For a society still struggling with ethnic reconciliation, particularly between the Albanian minority and Macedonian majority, the wiretaps also implicate Gruevski's coalition partner, the ethnicAlbanian party, Democratic Union of Integration (DUI). The DUI has been complicit in the current government's illegal activities, even in cases involving ethnic Albanians. For example, a recent International Crisis Group briefing reports that the wiretaps potentially implicate DUI in an alleged scapegoating effort by the current government in which seven ethnic Albanians were sentenced to life in prison for the murder of five ethnic Macedonians, despite the government "not knowing" who was guilty..$^{33}$ The political crisis reached it's peak in May $9^{\text {th }}$ when an intense armed battle broke out in the northern city of Kumanova between Macedonian police forces and a group of ethnic Albanians. The details of the clash remain uncertain, yet what is certain is the deadly nature of the fighting which resulted in the death of ten gunmen and eight policemen. The Kumanova events have led many Macedonians (ethnic Albanians and Macedonians alike) to believe that the government staged the events in order to relieve pressure from the wiretapping scandal, which had resulted in mass protests in Skopje, as the government was refusing to step down and set up an interim government. ${ }^{34}$

The current political crises in Macedonia underpin a number of issues that have prevented not only the consolidation of democracy, but ethnic reconciliation as well. This section of the article will therefore provide a historical-sociological analysis of the political transformation of Macedonia in

\footnotetext{
${ }^{30}$ European Commission and High Representative of the Union for Foreign Affairs and Security Policy, A new response to a changing Neighbourhood, (Brussels: High Representative of the Union for Foreign Affairs and Security Policy, European Commission,2011). Accessed July 21, 2015, http://eur-lex.europa.eu/LexUriServ/LexUriServ.do?uri=COM:2011:0303:FI N:en:PDF.

${ }^{31}$ International Crisis Group (ICG), Macedonia: Defusing the Bomb, Crisis Group Europe Briefing N75. (Skopje/Brussels: International Crisis Group, 2015), 5.

${ }^{32}$ European Commission, The former Yugoslav Republic of Macedonia: Recommendations of the Senior Experts' Group on systemic Rule of Law issues relating to the communications interception revealed in Spring 2015, (Brussels: European Commission, 2015), 6.

${ }^{33}$ ICG, Macedonia: Defusing the Bomb, 7.

${ }^{34}$ There have been numerous occasions in which the Macedonian government has supposedly engaged in dubious antiterrorist campaigns, despite international observers such as NATO unable to confirm the occurrence of such events. See: Edward P. Joseph, "The Balkans, Interrupted: The Protests in Macedonia are Only the Beginning," Foreign Affairs, (2015), accessed July 28, 2015, https://www.foreignaffairs.com/articles/southeastern-europe/2015-05-10/balkansinterrupted.
} 
order to better understand the current political crisis. In that respect, a brief historical overview of the early 1990s would provide an appropriate background through which to analyze the political development of the country.

The first post-communist elections of November 1990 produced three clear winners: the ethnicAlbanian Party for Democratic Prosperity (PDP) with 25 out of 120 seats in the national Parliament; the Internal Macedonian Revolutionary Organization-Democratic Party for Macedonian National Unity (VMRO-DPMNE) with 37 seats; and the Socialist Democratic Union of Macedonia (SDSM) with 31 seats. The two Macedonian parties represent the opposite ends of the political spectrum with VMRO-DPMNE representing the opposition movement to the communist party and SDSM as the successor communist party. Kacarska has argued that despite the two parties identifying with different ideological labels, "their declared orientations have remained largely unrelated to their respective socio-economic policy choices." 35 PDP on the other hand has focused exclusively on identity politics, while socio-economic issues are generally absent from the party's program. ${ }^{36}$ In 1994, however, PDP splintered into two factions: the moderate faction which remained part of PDP and the more radical faction, the Democratic Party of Albanians (DPA). PDP ultimately disappeared into political obsolescence, while a new ethnic-Albanian party, DUI, emerged as the leading ethnic-Albanian party after the 2001 conflict.

One of the first issues that stirred ethnic tensions in Macedonia came with the adoption of the new constitution in 1991. The constitution's preamble declared Macedonia to be "the national state of the Macedonian people", whereas the old Yugoslav constitution had defined the country as the nation of "the Macedonian people and the Albanian and Turkish minorities". This has perhaps been the biggest matter which Albanians has taken issue with, as it reduced the Albanian population into a minority group rather than a constitutive nation. Unsurprisingly, according to survey data conduced in the early 1990s, Albanians felt alienated in the post-socialist constitutional order as $86 \%$ considered themselves second-class citizens. ${ }^{37}$ PDP ultimately boycotted the especial session on the approval of the new constitution, while the Albanian population boycotted the 1992 national census. ${ }^{38}$ Additionally, the new citizenship law adopted in 1992 gave ethnic Macedonians living abroad automatic citizenship, while Macedonian minorities were required to reside in the country for a period of 15 years. Discrimination reflected more broadly in government employment, as despite consisting of about 25\% of the population, in 1997 Albanians represented only $10 \%$ of public servants and only $4 \%$ of the police force. ${ }^{39}$

Despite the discriminatory politics of the Macedonian state, the events that led to the 2001 armed conflict were in a way spontaneous and opportunistic. There was no prior indication that Macedonia would be engulfed in an internal armed conflict. However, the 1999 Kosovo War provided for an environment where Albanian groups within Macedonia, as well as ethnic Albanians from Kosovo and Serbia began an armed insurgence against the Macedonian state. Daskalovski has argued that at the early stages of the conflict, the insurgent group labeling themselves as the National Liberation Army had no clear aims, and claimed to be fighting against the 'SlavoMacedonian' oppression or a "Greater Albania"; while in the latter part of the conflict the rhetoric changed into fighting "for the human rights of Albanians in Macedonia." 40 The conflict ultimately ended through an internationally brokered peace deal known as the Ohrid Framework Agreement (OFA). OFA aimed at addressing the concerns of the Albanian minority, particularly amending the preamble of the constitution; greater political decentralization; equal representation in the public

\footnotetext{
${ }^{35}$ Simonida Kacarska, "The EU in Macedonian Party Politics - Consolidating and Driving” in EU integration and party politics in the Balkans, ed. Corina Stratula. (EPC Issue Paper No. 77, September 2014), 70. 
sector; making minority languages official languages in local governance units in which $20 \%$ of the population was a non-majority group; and finally a principle of double-majority in which national legislation which affected "culture, use of language, education, personal documentation, and use of symbols, as well as laws on local finances, local elections, the city of Skopje, and boundaries of municipalities" would require the majority of representatives in the national Parliament as well as the majority of votes from representative of non-majority communities.

OFA, however, was met with resistance by the Macedonian population. According to survey data, $51 \%$ of ethnic Macedonians disapproved of the agreement, while only $44 \%$ approved it; the Albanian population on the other hand approved it with $78 \%{ }^{41}$ The nationalist VMRO even attempted to organize a referendum against the agreement, but ultimately failed in their effort after pressure from the EU and US. The implementation of OFA, however, while effective in addressing certain minority issues, has failed in others, while at the same time having a number of unintended consequences. The most effective of OFA's initiatives has arguably been the language initiative, which has resulted in Albanian becoming an official language in 29 out of 85 municipalities. Yet even the language initiative has resulted in a number of unintended consequences. As Mirjana Maleska explains: language has become an impediment to ethnic reconciliation as not only is either side been unwilling to learn the language of the "other", but at the same time, language is used as a mechanism of differentiation and separation. ${ }^{42}$ Equal representation has also been effective to a certain extent. For example, by 2004, Albanian representation in the police force had reached $13.3 \%{ }^{43}$; while by 2015 , Albanians were represented in $18.9 \%$ of non-managerial and $14.5 \%$ of managerial jobs in the public sector. ${ }^{44}$ It is worth highlighting that the implementation of OFA resulted in the negligence of other non-majority groups such as Turks, Serbs, Vlachs, and Roma. ${ }^{45}$

Other OFA initiatives, however, have had more negative consequences than positive ones. Take political decentralization as an illustration. According to an OSCE survey on decentralization in Macedonia, most municipal leaders and administrators believe that there has been a significant transfer of power to the municipal level, especially relating to education, communal services, and urban planning; however, at the same time, most survey participants felt that the biggest challenge to the effective implementation of their competences has been lack of financial resources. ${ }^{46}$ Thus, as municipal leaders are dependent on the central government for financial resources, their autonomy as decentralized governing units decreases. According to an International Crisis Group report, the Association of the Units for Local Self Government has "fallen under the patronage of the ruling parties." ${ }^{47}$ In an analysis of decentralization in Macedonia, Lyon has gone as far as to argue that while decentralization has increased the space of local citizens to participate in local matters, the over-dominance of national parties has undermined decentralization and its potential benefits. ${ }^{48}$ The double-majority principle on the other hand which was supposed to act as a procedural safeguard for minority interests in policy-making has been sidelined through legal loopholes which has allowed the government to implement a major nationalist project (the Skopje 2014 Project) without the approval of non-majority groups. ${ }^{49}$

It would be a hard sell to argue that Macedonia has achieved either democratic consolidation or reconciled its ethnic grievances. While it would be even more difficult to accept that European

\footnotetext{
${ }^{41}$ Brunnbauer, The Implementation of the Ohrid Agreement, 13.

${ }^{42}$ Reka, The Ohrid Agreement, 65.

${ }^{43}$ Ibid., 61.

${ }^{44}$ ICG, Macedonia: Defusing the Bomb, 8.

${ }^{45}$ According to official Macedonian government statistics, from 2002 until 2006, it was only the Albanian non-majority group which benefited from the implementation of OFA in public sector employment, while the rest of the groups did not see an improvement in public employment. See: Koinova, Challenging Assumptions of the Enlargement Literature, 823.

${ }^{46}$ OSCE, Decentralization Assessment Report 2006-2011, December 2011, (Skopje, Macedonia: OSCE Mission to Skopje), 6-8.

${ }^{47}$ International Crisis Group, Macedonia: Ten Years After the Conflict, Europe Report N`212 - 11 (August 2011), 20.

${ }^{48}$ Aisling Lyon, "Political Decentralization and the Strengthening of Consensual, Participatory Local Democracy in the Republic of Macedonia," Democratization 22, no. 1 (2015).

${ }^{49}$ ICG, Macedonia: Ten Years After the Conflict, 3.
} 
integration has not had some negative consequences for the consolidation of democracy and ethnic reconciliation. In the following section, this article will engage in a theoretical discussion in order to better discern the mechanisms through which the political transformation of Macedonia, in conjunction with the process of European integration has failed to adequately protect minority rights.

\section{Discussion}

I will begin this section with a look at some of the theoretical debates on the link between ethnicity (minorities) and democratization. Conceptually, democracy is defined either in minimalist or in maximalist terms. Thus whereas a minimalist definition of democracy would constitute simply free and fair elections; a maximalist definition incorporates other democratic qualities such as a vibrant civil society, an independent judiciary, and even political culture. ${ }^{50}$ Therefore, in reference to the protection of minority rights, it is the maximalist definition of democracy that more accurately captures minority issues. Thus when this article refers to democratic consolidation, it is referring to the more maximalist definition of democracy. The relationship between the two-ethnicity and democracy-however, remains unclear as there is no consensus whether ethnicity hinders democratization. In an assessment of the relationship between the two concepts, Beissinger has argued that while ethnicity does matter for democratization, it seldom does so in a direct way. ${ }^{51}$ Similarly, in an assessment of the relationship between nationalism and democracy, Helbling finds that rather than being competing logics, the compatibility of the two is more a matter of degree. ${ }^{52}$

The role of minority rights in the failure of democratic consolidation in Macedonia has often been cited as one of the core causes. To a certain extent that is accurate. Minority issues have been at the forefront of Macedonia's political transformation since the end of communism. However, without properly placing ethnicity in the process of democratization, it is hard to disentangle the causal mechanism of that relationship. As Schmitter and Santiso have argued, in addition to the what questions, that is, what to reform, politicians are also faced with questions of when. ${ }^{53}$ That is, when to change something, in what order, and what tempo. The temporal dimension of democracy is arguably as important as the structural and functional dimension and is of particular significance in divided societies as it interacts with heartfelt issues such as language, culture and identity. Thus when a transition is interacted with a divided society, political decisions are more likely to have unintended consequences.

For example, Beissinger has argued that the injection of political competition can result in "ethnic outbidding" as politicians seek to maximize popular support from particular ethnic groups. ${ }^{54}$ Furthermore, as politicians learn to play the "ethnic card" in orders to gain popular support, ethnic grievances are exacerbated. ${ }^{55}$ It is worth pointing out that during the early phase of the democratization process, ethnic politics are more pronounced, as the absence of interestbased politics turns ethnic politics into the only game in town, especially for ethnic-based parties. The Macedonian case exemplifies this effect very clearly. As was discussed earlier, the four major political parties in Macedonia have not shown any levels of ideological institutionalization along the left-right dimension, while ethnic-Albanian parties in particular have focused exclusively on identity politics. According to the latest Bertelsmann Stiftung's Transformation Index, it is difficult to see how the main political parties aggregate societal interests; while the perception among the population is that political parties represent only "narrow cliquish interests" that do not benefit the general welfare of society. ${ }^{56}$ The most interesting finding from a recent study on democratization in

\footnotetext{
${ }^{50}$ Andreas Schedler, “What is Democratic Consolidation?,” Journal of Democracy 9, no. 2 (1998).

${ }^{51}$ Mark R. Beissinger, "A New Look at Ethnicity and Democratization," Journal of Democracy 19, no. 3 (2008), 87.

${ }^{52}$ Marc Helbling, "Nationalism and Democracy: Competing Or Complementary Logics?," Living Reviews in Democracy 4 (2013).

${ }^{53}$ Philippe C. Schmitter and Javier Santiso, "Three Temporal Dimensions to the Consolidation of Democracy," International Political Science Review 19, no. 1 (1998).

${ }^{54}$ Beissinger, A New Look at Ethnicity and Democratization, 85.

${ }^{55}$ Ibid.

${ }^{56}$ Bertelsmann Stiftung's Transformation Index (BTI), 2014 (Macedonia Country Report, Gütersloh: Bertelsmann Stiftung), 15 .
} 
Macedonia shows that even the ethnic-Albanian party, DUI, has "disenfranchised Albanians who are not party members from potential positions in the local civil service and public administration." 57

The politicization of the civil sector, particularly among ethnic-based political parties, perhaps provides the biggest indication of the manner through which minority rights have failed to be properly institutionalized in Macedonia. This is not a unique feature to the Macedonian political system, as the politicization of the civil sector is a common symptom of transitioning societies. Yet what is unique to the Macedonian case is the manner through which ethnic parties have been incorporated into the corruptive scheme of Macedonian politics. Ethnic parties have thereforefailed to represent minority interests, as more narrow individual and cliquish interests have been prioritized.

When European integration is incorporated into this theoretical discussion, we can discern a number of patterns that have either hindered or advanced the protection of minority rights and democratic consolidation. The reason for this is the manner through which the EU has advanced the integration process. According to Grabbe, the EU has assumed that integration and democratization are part of the same process, regardless of the fact that "EU policies and regulatory models were created to fit economies and societies at a very different level of development." ${ }^{58}$ Therefore, under certain conditions, integration is problematic for democratization and minority rights because it advances norms and policies that are not necessarily compatible with an effective promotion strategy. Rather, a one-size fits all approach is adopted as acceding states must adopt EU policies as they stand, otherwise the European project risks setbacks. In other words, under certain conditions, human rights and democracy promotion by the EU may not necessarily result in positive change.

In addition to the failure of the EU's promotion strategies, enlargement as a foreign policy goal has lost priority, which in effect has diminished the Union's influence in the Western Balkans. Part of this is attributed to enlargement fatigue and the recent global financial and Euro zone crisis. However, in the case of Macedonia, an accession perspective has lost further credibility as a result of the country's enduring name dispute with Greece. ${ }^{59}$ Thus when in 2008 Greece vetoed Macedonia's entry into NATO due to the latter's name, the Gruevski government turned the rejection into a political victory by playing into ethnic Macedonian claims of historical grievances ${ }^{60}{ }^{2}$ Interesting to highlight that despite the diverging views on a number of issues between the constitutive nations of the Macedonian state, most Macedonians and its non-majority groups are of the view that the name dispute is postponing integration toward Western led institutions such as EU and NATO. ${ }^{61}$ The name dispute has also prevented the beginning of accession negotiations with the EU despite the country's candidate status since 2005. According to the latest Progress Report on Macedonia, the European Commission contends that it is ready to open negotiations, yet the name dispute with Greece has prevented that from happening (European Commission 2014). The failure of the EU to follow-up on its enlargement promise has therefore allowed for nationalistic tendencies to flourish within the current government.

According to the latest Freedom House Nations in Transit Report, Macedonia's overall democracy score has deteriorated yearly since 2007, particularly the subcategories of media and judicial independence. ${ }^{62}$ As the current government is attempting to entrench its political power,

\footnotetext{
${ }^{57}$ Lyon, Political Decentralization, 163.

${ }^{58}$ Heather Grabbe, "European Union Conditionality and the Acquis Communautaire," International Political Science Review 23, no. 3 (2002), 253.

${ }^{59}$ The Greek-Macedonian dispute concerning the latter's name revolves around the historic region Macedonia. Greece has been officially unwilling to recognize Macedonia by its official name "Republic of Macedonia" as the Greeks claim that would allow Macedonia to lay territorial claims in parts of present day Greece-historically part of the region of Macedonia.

${ }^{60}$ ICG, Macedonia: Ten Years After the Conflict, 1.

${ }^{61}$ Ljupco Risteski and Armanda Kodra Hysa, "Strategies for Creating the Macedonian State and Nation and Rival Projects Between 1991 and 2012," in Strategies of Symbolic Nation-building in South Eastern Europe, ed. Pål Kolstø, (Burlington: Ashgate Publishing, Ltd., 2014), 168.

According to the same 2011 survey, $77 \%$ of Macedonians, $80 \%$ of Albanians, and $71 \%$ of other non-majority groups were of the view that the name dispute is slowing down EU and NATO integration.

${ }^{62}$ Sylvana Habdank-Kołaczkowska, "Nations in Transit 2015: Democracy on the Defensive in Europe and Eurasia," (Washington, DC: Freedom House, 2015), 25.
} 
Macedonian society has also shown signs of democratic resilience. Following the release of the wiretaps in February of this year, large-scale protests began developing in Skopje calling for the step-down of the current government. What stood out as unique in the 2015 anti-government protests was the fact that ethnic Albanians and Macedonians alike protested together in solidarity against the present government. This is a rare occurrence, as according to Shikova, civil-motivated protests are generally absent in Macedonia as more ethnic and partisan motivated protest have dominated the sphere of civil unrest. ${ }^{63}$ The recent crisis therefore provided an opportunistic window through which to reconcile ethnic grievances between the major groups in Macedonia. Yet despite this opportune moment, the Gruevski government has managed to divert attention from the protests to the ethnically charged May events in Kumanova. It is highly likely that the early scheduled elections of December 2016 will result in a victory for the opposition. Yet what remains uncertain is the extent to which a change in administration will provide for a environment which ethnic reconciliation takes place, democratic qualities are improved, and integration toward Western led institutions begins in earnest.

\section{Conclusion}

What we've seen in the political transformation of Macedonia is the institutionalization of a pattern of politics that has disregarded and neglected minority rights. This conclusion is widely counterintuitive to what was discussed above, as there was clearly a minority rights component to the Macedonian transformation. However, while on the surface minority rights were at the forefront of the country's political transformation, below the surface, individualistic powerdriven and corrupt motives were the driver of political decisions, rather than genuine concerns for minority rights. This was most apparent in DUI's politicization of civil sector employment, which disenfranchised ethnic Albanians not supportive of the party. The unwillingness of the Albanian based parties to demand genuine political change for minority protection was only exacerbated by the disapproval of the OFA by ethnic Macedonians, which provided ethnic Macedonian parties with popular support for nationalistic projects.

It is becoming apparent in the Western Balkans that as EU influence is diminishing, political reforms have ceased, and authoritarian tendencies have been on the rise. Macedonia exemplifies this regional trend more clearly than any other one. For the EU to improve its promotion strategies, however, it must first address some of its internal contradictions. In terms of democracy promotion, it must first develop country specific promotion strategies informed by previous experiences. Following the 2004/07 Eastern Enlargement and the troubling democratic performance of Bulgaria and Romania after accession, the EU took proactive steps to improve its enlargement policy. Specifically, this included the introduction of two new chapters in accession negotiations-Chapter 23 on Judiciary and Fundamental rights, and Chapter 24 on Justice, Freedom and Security. According to an EU official, lessons learned from the Eastern Enlargement-specifically the negligence of the political criteria-have resulted in the reinforcement of democracy promotion. ${ }^{64}$ Yet, even if we assume that the new enlargement policy is an improvement from the previous one, there is no reason to believe, for example, that the same policy will have the same effects in post-conflict Macedonia and Serbia compared to Albania, which did not undergo a violent conflict in the post-communist period. Additionally, in reference to minority rights, the EU has been criticized for a blatant display of hypocrisy. Minority rights consist of a major components of the EU's enlargement policies, however, within its own territories, EU members have failed to apply the same protective measures as the ones promoted in Eastern Europe. ${ }^{65}$

\footnotetext{
${ }^{63}$ Natalija Shikova, "Exercising the Right to Protest: The Indicator of Country's Democratic Capacity and the Case of Macedonia" Facta Universitatis, Series: Law and Politics 12, no. 2 (2014).

${ }^{64}$ Peter Simmons, The Impact of EU Democracy Promotion: The View from Brussels, (London: Jean Monnet Centre of Excellence in European Law and Governance: King's College London, 2011), 22.

${ }^{65}$ Nelli Babayan and Daniela Huber, "Motioned, Debated, Agreed? Human Rights and Democracy Promotion in International Affairs," Transworld. (Working Paper 06, 2012).
} 
Perhaps the EU's best course of action would be to tap into those common views that all Macedonians share toward Western led institution, particularly by addressing Macedonia's name dispute with Greece, which has acted as a stumbling block for NATO integration and the beginning of EU negotiations. Additionally, the EU has much experience to learn from. The Slovak experience showed that European integration can be a powerful force in defeating a "authoritarian" regime. Thus by applying public pressure in a highly euro-enthusiastic society such as Macedonia, the EU can force domestic change. However, a delicate line most be walked between security issues on the one hand which have the tendency to advance nationalist goals, and minority concern which also have the tendency to institutionalize ethnic divisions.

It should not, however, be misconstrued that this article is underplaying the importance of international forces. Yet with that being said, it is the argument of this article that while on the one hand international forces have been effective in preventing potential genocidal violence, on the other hand, they have been less effective, and under certain conditions counterproductive in reconciling ethnic tensions. It is therefore precisely in the context of a post-conflict/genocidal legacy and an unconsolidated democratic system that ethnic reconciliation in Macedonia has been particularly difficult to accomplish.

The findings of this heuristic case study have shown that not only are democratic consolidation and minority rights protection mutually inclusive, but that an effective promotion strategy that addresses only one of these issues, would under certain conditions negate the other. The case study therefore confirms much of the preexisting literature-European integration is only partially effective in promoting domestic change, while under certain conditions there is even a possibility of unintended consequences. However, the Macedonian case does add something particular, as unlike any of the Eastern Enlargement cases, Macedonia represents a post-conflict situation in which minority concerns were more pertinent and delicate than previous cases of European integration. It is highly unlikely that the failure of European integration in Macedonia and the Western Balkans will lead to another genocidal war among the constitutive nations of the region. However, it is up to regional organizations with a normative attraction to provide an impetus through which s stagnated political transitions such as the Macedonian one can move forward.

\section{Bibliography}

Ash, Timothy Garton. “Europe's Endangered Liberal Order." Foreign Affairs. 77, (1998): 51-65. http://dx.doi.org/10.2307/20048788

Babayan, Nelli and Daniela Huber. "Motioned, Debated, Agreed? Human Rights and Democracy Promotion in International Affairs." Transworld. Working Paper 06, 2012.

Beissinger, Mark R. "A New Look at Ethnicity and Democratization." Journal of Democracy 19, no. 3 (2008): 85-97. http://dx.doi.org/10.1353/jod.0.0017

Bieber, Florian. Institutionalizing Ethnicity in the Western Balkans: Managing Change in Deeply Divided Societies. Flensburg: European Centre for Minority Issues, 2004.

Brunnbauer, Ulf. "The Implementation of the Ohrid Agreement: Ethnic Macedonian Resentments." JEMIE 1 (2002): 2-24.

Brzezinski, Zbigniew. "Post-Communist Nationalism." Foreign Affairs, 68, no. 5 (1989): 1-25. http://dx.doi.org/10.2307/20044197

BTI-- Bertelsmann Stiftung's Transformation Index. Macedonia Country Report. Gütersloh: Bertelsmann Stiftung, 2014.

Burnell, Peter. "Promoting Democracy." Government and Opposition 48, no. 2 (2013): 265-287. http://dx.doi.org/10.1017/gov.2012.4

Daskalovski, Zhidas. "Democratic Consolidation and the 'stateness' Problem: The Case of Macedonia." The Global Review of Ethnopolitics 3, no. 2 (2004): 52-66. http://dx.doi. org/10.1080/14718800408405165

Eckstein, Harry. "Case Study and Theory in Political Science," In Handbook of Political Science, Vol. 3, edited by Fred I. Greenstein and Nelson W. Polsby, 79-137. Reading: Addison Wesley Publishing Company, 1975. 
Engstrom, Jenny. "Multi-Ethnicity Or Bi-Nationalism-the Framework Agreement and the Future of the Macedonian State." JEMIE 1 (2002): 2-21.

Ethier, Diane. "Is Democracy Promotion Effective? Comparing Conditionality and Incentives." Democratization 10, no. 1 (2003): 99-120. http://dx.doi.org/10.1080/13510340312331293947a

European Commission. The former Yugoslav Republic of Macedonia: Recommendations of the Senior Experts' Group on systemic Rule of Law issues relating to the communications interception revealed in Spring 2015, Brussels, June 8, 2015.

- - - . The former Yugoslav Republic of Macedonia Progress Report. Brussels, October 2014. COM(2014)700 final of 8.10.2014.

European Commission and High Representative of the Union for Foreign Affairs and Security Policy. A new response to a changing Neighbourhood, Brussels, 25 May. COM (2011) 303.final). Accessed July 21, 2015. http://eurlex.europa.eu/LexUriServ/LexUriServ.do?uri=COM:2011 :0303:FIN:en:PDF.

Grabbe, Heather. The EU's Transformative Power: Europeanization through Conditionality in Central and Eastern Europe. New York: Palgrave Macmillan, 2006. http://dx.doi. org/10.1057/9780230510302

- - -. "European Union Conditionality and the Acquis Communautaire." International Political Science Review 23, no. 3 (2002): 249-268. http://dx.doi.org/10.1177/0192512102023003003

Gurr, Ted Robert. "Options for the prevention and mitigation of genocide: strategies and examples for policy-makers." Politorbis 47, no. 2 (2009): 47-50.

Habdank-Kołaczkowska, Sylvana. "Nations in Transit 2015: Democracy on the Defensive in Europe and Eurasia." Washington, DC: Freedom House. 2015.

Helbling, Marc. "Nationalism and Democracy: Competing Or Complementary Logics?." Living Reviews in Democracy 4 (2013).

Hinton, Alexander. Why Did They Kill? Cambodia in the Shadow of Genocide. Berkeley: University of California Press, 2005.

International Crisis Group (ICG). Macedonia: Defusing the Bomb. July 9, 2015. Crisis Group Europe Briefing, $\mathrm{N}^{\circ} 75$. Skopje/Brussels.

- - - Macedonia: Ten Years After the Conflict. August 11, 2011. Europe Report No212.

Joseph, Edward P. "The Balkans, Interrupted: The Protests in Macedonia are Only the Beginning." Foreign Affairs. (May 10, 2015), Accessed July 28 ${ }^{\text {th }}$, 2015. https://www.foreignaffairs.com/ articles/southeastern-europe/2015-05-10/balkans-interrupted.

Kacarska, Simonida. "The EU in Macedonian Party Politics-Consolidating and Driving." In EU integration and party politics in the Balkans, ed. Corina Stratula, 69-82. EPC Issue Paper No. 77. (September 2014).

Koinova, Maria. "Challenging Assumptions of the Enlargement Literature: The Impact of the EU on Human and Minority Rights in Macedonia." Europe-Asia Studies 63, no. 5 (2011): 807832. http://dx.doi.org/10.1080/09668136.2011.576023

Linz, Juan and Alfred Stepan, Problems of Democratic Transition and Consolidation: South America, Southern Europe, and Post-Communist Europe. Baltimore, Md: Johns Hopkins University Press, 1996.

Lyon, Aisling. "Political Decentralization and the Strengthening of Consensual, Participatory Local Democracy in the Republic of Macedonia." Democratization 22, no. 1 (2015): 157-178. http://dx.doi.org/10.1080/13510347.2013.834331

Minorities at Risk Project (MAR). Chronology for Albanians in Macedonia. 2004-2015

Minorities at Risk Project, (2015). Accessed July 28, 2015, http://www.cidcm.umd.edu/mar/ chronology.asp?groupId=34301.

Mitchell, James A. "The Assimilation of Racial Minorities into Central Eastern European Societies in the 21 ${ }^{\text {st }}$ Century: Central Eastern and Western Europe in Comparative Perspective." Journal of Political Science \& Public Affairs 3, no. 1 (2015). http://dx.doi.org/10.4172/2332$\underline{0761.1000150}$

Moravcsik, Andrew. "Explaining International Human Rights Regimes: Liberal Theory and Western Europe." European Journal of International Relations 1, no. 2 (1995): 157-189. http://dx.doi.org/10.1177/1354066195001002002 
Nedelsky, Nadya. 2003. “Constitutional Nationalism's Implications for Minority Rights and Democratization: The Case of Slovakia." Ethnic and Racial Studies 26, no. 1 (2003): 102-128. http://dx.doi.org/10.1080/01419870022000025298

Nitzova, Petya. "Bulgaria: Minorities, Democratization, and National Sentiments." Nationalities Papers 25, no. 4 (1997): 729-739. http://dx.doi.org/10.1080/00905999708408537

Offe, Claus. "Capitalism by Democratic Design? Democratic Theory Facing the Triple Transition in East Central Europe." Social Research, (1991): 865-892.

OSCE, Decentralization Assessment Report 2006-2011, December 2011. Skopje, Macedonia: OSCE Mission to Skopje.

Pevehouse, Jon C. "Democracy from the Outside-in? International Organizations and Democratization." International Organization 56, no. 3 (2002): 515-549.

Poast, Paul and Johannes Urpelainen. "How International Organizations Support Democratization: Preventing Authoritarian Reversals Or Promoting Consolidation?." World Politics 67, no. 1 (2015): 72-113.

Popovska, Biljana and Zhanet Ristoska. "Process of Reconciliation in a Postconflict Macedonia." Academicus International Scientific Journal 11 (2015): 63-76. http://dx.doi.org/10.7336/ academicus.2015.11.05

Pridham, Geoffrey. Designing Democracy: EU Enlargement and Regime Change in Post-Communist Europe. New York: Basingstoke, 2005. http://dx.doi.org/10.1057/9780230504905

Ram, Melanie H. 2003. "Democratization through European Integration: The Case of Minority Rights in the Czech Republic and Romania." Studies in Comparative International Development 38, no. 2 (2003): 28-56. http://dx.doi.org/10.1007/BF02686267

Reka, Armend. "The Ohrid Agreement: The Travails of Inter-Ethnic Relations in Macedonia." Human Rights Review 9, no. 1 (2008): 55-69. http://dx.doi.org/10.1007/s12142-007-0029-z

Risse, Thomas, Stephen C. Ropp, and Kathryn Sikkink, The Power of Human Rights: International Norms and Domestic Change. New York: Cambridge University Press, 1999. http://dx.doi.org/10.1017/CBO9780511598777

Risteski, Ljupco and Armanda Kodra Hysa. "Strategies for Creating the Macedonian State and Nation and Rival Projects Between 1991 and 2012," In Strategies of Symbolic Nation-building in South Eastern Europe, edited by Pål Kolstø, 165-200. Burlington: Ashgate Publishing, Ltd., 2014.

Rupnik, Jacques and Jan Zielonka. "Introduction: The State of Democracy 20 Years on Domestic and External Factors." East European Politics E Societies 27, no. 1 (2013): 3-25.

Schedler, Andreas. "What is Democratic Consolidation?." Journal of Democracy 9, no. 2 (1998): 91-107. http://dx.doi.org/10.1353/jod.1998.0030

Schimmelfennig, Frank and Hanno Scholtz. "EU Democracy Promotion in the European Neighbourhood Political Conditionality, Economic Development and Transnational Exchange." European Union Politics 9, no. 2 (2008): 187-215. http://dx.doi.org/10.1177/1465116508089085

Schmitter, Philippe C. and Javier Santiso. "Three Temporal Dimensions to the Consolidation of Democracy." International Political Science Review 19, no. 1 (1998): 69-92. http://dx.doi. org/10.1177/019251298019001005

Shaw, Martin. What is genocide? Second Edition. Malden: Polity, 2015.

Shikova, Natalija. "Exercising the Right to Protest: The Indicator of Country's Democratic Capacity and the Case of Macedonia." Facta Universitatis, Series: Law and Politics 12, no. 2 (2014): 93102.

Simmons, Peter. The Impact of EU Democracy Promotion: The View from Brussels (London: Jean Monnet Centre of Excellence in European Law and Governance: King's College London, 2011).

Subotić, Jelena. "Out of Eastern Europe Legacies of Violence and the Challenge of Multiple Transitions." East European Politics \& Societies 29, no. 2 (2015): 409-419. http://dx.doi. org $/ 10.1177 / 0888325415569763$

Székely, István Gergő and István Horváth. “Diversity Recognition and Minority Representation in Central and Southeast Europe: A Comparative Analysis." Nationalities Papers 42, no. 3 (2014): 426-448. http://dx.doi.org/10.1080/00905992.2014.916660 
Vachudova, Milada Anna. "External Actors and Regime Change: How Post-Communism Transformed Comparative Politics." East European Politics and Societies and Cultures 29, no. 2 (2015): 519-530. http://dx.doi.org/10.1177/0888325415571411

- - - Europe Undivided: Democracy, Leverage, and Integration After Communism. Oxford University Press, 2005.

Whitehead, Laurence. The International Dimensions of Democratization: Europe and the Americas: Europe and the Americas. Oxford: Oxford University Press, 2001. 